\title{
LIFE HISTORY OF PREDATORY MITE PULAEUS MARTINI (DEN HEYER), (ACARI: PROSTIGMATA: CUNAXIDAE) FED ON DIFFERENT DIETS
}

\author{
KHALIL, A. M. , E. M. A. YASSIN and M. M. EL-SEBAAY \\ Plant Protection Research Institute, ARC, Dokki, Giza, Egypt
}

(Manuscript received $2^{\text {nd }}$ January 2012)

\begin{abstract}
This work aimed to study different biological aspects of the predatory mite, Pulaeus martini (Den Heyer) when fed on different diets mainly free living nematode, Rhabditella muscicola Chitwood and two different fungi (Fusarium oxysporum Schlechtendahl and Pythium spinosum Sawada at 20, 25, 30 and $35 \pm 2{ }^{\circ} \mathrm{C}$ and relative humidity $75 \pm 5 \%$ R.H. in laboratory. Obtained data indicated that the different biological aspects of $P$. martini was significantly affected by different mentioned diets and temperatures. The male lasted shorter time than female in different periods. The life periods of individuals increased as well as temperature increased from 20 up to $35^{\circ} \mathrm{C}$. The lowest period of life cycle recorded when the male fed on free living nematode ( 10.89 days) at $35^{\circ} \mathrm{C}$, while it elongate to (23.89 days) was male reared on F. oxysporum at $20^{\circ} \mathrm{C}$. Female longevity recorded the longest period when it fed on F. oxysporum at $20{ }^{\circ} \mathrm{C}$ (37.21 days) while the shortest longevity period recorder at $35^{\circ} \mathrm{C}$. (12.16 days). On the other hand the free living nematode elongated the life span time for predatory mite females at $20^{\circ} \mathrm{C}$ it lasted 62.48 days, but the shortest time was recorded when female individuals fed on F. oxysporum at $35^{\circ} \mathrm{C}$ (37.89 days). From the obtained results also, it was noticed that the best diet for rearing the cunaxid mite $P$. martini was $F$. oxysporum at $25^{\circ} \mathrm{C}$ where it recorded the highest number of deposited eggs (73.79) but the least favorable one for feeding was the fungus $P$. spinosum at 35 ${ }^{\circ} \mathrm{C}$ (48.71 eggs).

Key words: Cunaxid mite -Pulaeus martini - development- dietstemperatures
\end{abstract}

\section{INTRODUCTION}

Mites belonging to the family Cunaxidae are well known predators of other harmful mites and small soft bodied insects, Smiley (1992). Very little is known about the biology of the Pulaeus Den Heyer species. Walter \& Kaplan (1991) reported them feeding on larvae of rootknot nematodes (Meloidogyne spp.). Schruft (1971) reported that Cunaxoides oliveri is a predator of grape wine mite Clepitrimerus vitus. Walter and Kaplan (1991) found Coleoscirus simplex colonizes greenhouse pot cultures of root knot nematodes (Meloidogyne spp.) in Florida where it feeds on vermiform nematodes and other soil arthropods. They also studied the feeding behavior of Cunaxidae. Arbabi et al., (2002) reported the family Cunaxidae as in important 
predatory family from Sistan Baluchestan and Hormozgan provinces of Iran. Tagore and Putatunda (2003) reported that cunaxid mites were important predators in the ornamental plants in Haryana. De-Oliveira and Daemmon (2003) found that cunaxid mites are important component of fauna in the dust samples from the rural dwellings of Zona da Mata region Brazil. Very little is known about the biology of the genus Pulaeus Den Heyer. Walter and Kaplan (1991) reported them feeding on larvae of rootknot nematodes (Meloidogyne spp.). About 26 species of Pulaeus Den Heyer are known all over the world., De Castro and Den Heyer (2004).In the presence of more than two prey species, a generalist predator should select the one that assures higher fitness, Charnov (1976). Therefore, the prey preference of a predator may be affected not only by characteristics of a prey item as food, but also by the microenvironment or architecture produced by a prey species (Furuichi et al., 2005). This is the report of Pulaeus biology in Egypt, where very little is known about its diversity and behavior. The life cycles of only 6 of the nearly 260 described Cunaxid species have been studied (Schruft 1971, Zaher et al., 1975, Taha et al., 1988, Walter and Kaplan 1991, Sathiamma 1995, Arbabi and Singh 2000, Tatiane et al., 2010. These studies have shown the ability of cunaxids to prey upon mites of the Tetranychoidea and Eriophyoidea, as well as other small arthropods and nematodes. Therefore, the present work was undertaken to introduce a detail study on the biological aspects of the cunaxid mite, Pulaeus martini (Den Heyer) when fed on different diets, free living nematode, Rhabditella muscicola Chitwood and two different fungi (Fusarium oxysporum Schlechtendahl and Pythium spinosum Sawada) under laboratory conditions.

\section{MATERIALS AND METHODS}

The cunaxid mite, Pulaeus martini was extracted from soil under maize and cotton plants in El-Menofia Governorate. Three adults female and males of the mite were placed in screening cells $(2.5 \mathrm{~cm}$ in diameter), with a layer of mixture of Plaster of Paris and Charcoal (9:1) on its bottom to depth $5 \mathrm{~mm}$ and covered with slide cover and binded by robber band. The cells were supplied with food and kept at $25{ }^{\circ} \mathrm{C}$ and about $75 \pm 5 \%$ R.H. Water drops were added when needed. For individual unit rearing, newly deposited eggs were transferred each to a rearing plastic cell. Each newly hatched larva was supplied with different tested food free living nematode, Rhabditella muscicola Chitwood and two different fungi (Fusarium oxysporum Schlechtendahl and Pythium spinosum Sawada rent fungi (Fusarium oxysporum and Pythium spinosum and consumed food was replaced every 2-3 days interval with 
another new one till reaching maturity stage. The stock of the three different diets already obtained from Plant Pathology Research Institute, Agricultural Research Center under laboratory conditions were conducted at 20, 25, 35 and $35{ }^{\circ} \mathrm{C}$ and relative humidity $75 \%$ R.H. All obtained data are presented as means \pm S.D.of twenty replicates and all observation recorded by helping stereomicroscope. The obtained data were subjected to one-way analysis of variance (ANOVA) and means were separated by Duncan's multiple range test (Duncan, 1955).

\section{RESULTS AND DISCUSSION}

Behavior: Life history of females and males of Pulaeus martini pass through one larval and three nymphal stages (protonymph, deutonymph, tritonymph) before reaching adulthood. Active immature individuals usually enters a resting or quiescent stage before entrance the following stage.

Mating: Laboratory observations showed that adults tended to mate immediately after their emergence. The male is able to copulate more than one female, but the females accepted one copulation. Just before mating, the male showed more activity by running around the female, and then it manipulated itself underneath the female, bending its opithosomal region upward and forward to meet that of female, usually lasted about 5-7 minutes

Oviposition :Females of Pulaeus martini usually deposited its eggs singly after preoviposition period between 2.48-5.98 days. Newly laid eggs were creamy in color.

Hatching: As incubation proceeds, the embryo grows and limits itself to any of the egg sides, then a longitudinal slit occurs medially and hatching larvae crawls outside the egg shell.

Moulting: During this study, it was noticed that before moulting, each immature stage of the cunaxid mite, Pulaeus martini enters into a quiescent stage during which, the mite stop feeding and moving. The individuals stretch their chelicera, palps backwardly along the sides of the body. Immediately before moulting a dorsal transverse rupture occurs between the propodosoma and hysterosoma. The mite tries to disengage itself from the old skin by twisting movements and subsequently withdraws the forelegs and the anterior part of the body outside. Afterwards, the mite crawl forwardly trying to get ride of the posterior part of the exuvia. Color of the newly emerged larva is usually orange, then changes gradually darker after feeding.

Incubation period: The tabulated data in Table (1) indicated that the different temperatures and tested diets had significant affected on the incubation period of the cunaxid mite, P. martini. It was found that this period took $(5.97,5.87 \& 5.81)$, (4.88, 
$4.96 \& 491),(3.87,3.94 \& 3.80),(2.99,2.87 \& 2.84)$ days when the mite males fed on free living nematode, Fusarium oxysporum and Pythium spinosum at 20, 25, 30 and $35{ }^{\circ} \mathrm{C}$, respectively. However, this period in case of females lasted $(5.98,5.94 \&$ $5.8),(4.84,4.96 \& 4.92),(3.76,3.88 \& 3.76),(3.13,3.34 \& 3.27)$ days at the same conditions, respectively. From the same table, it was observed that there was highly significant differences between the different mites fed on different diets at different temperatures, L.S.D. at 0.05 level $=0.059 \& 0.0789$ and $0.018 \& 0.02$ for both temperature and diet effects for males and females, respectively.

Life cycle: The influence of different diets on $P$. martini life cycle can be summarized in Table (1) which revealed that the mean duration periods were shorter in case of male individuals then those of female individual where recorded $(23.44,23.84$ \& 23.34), (18.33, $17.97 \& 18.62)$, (15.15, $15.21 \& 15.69)$, (10.89, $10.94 \& 10.95)$ days when the males fed on the above mentioned diets at 20, 25, 30 and $35{ }^{\circ} \mathrm{C}$, respectively. On the other hand the females lasted $(26.94,26.96 \& 26.6),(24.61,24.5$ \& 24.06), (19.17, $19.52 \& 19.35)$, and $(15.12,15.7 \& 15.06)$ days when fed on the same previously diets at the same laboratory conditions. The statistical analysis of current data revealed that there were very highly significant differences between the mite individuals when fed on the tested diets at the different temperatures, L.S.D. at 0.05 level $=0.056$ and 0.052 for effect of diets and temperatures, in case of males, respectively and 1.59 and 0.176 in case of females individuals, respectively.

Longevity: As shown in Table (1), females and males longevity was maximal at 20 ${ }^{\circ} \mathrm{C}$ and reduced at higher temperature. During this period, female lived longer at 20 ${ }^{\circ} \mathrm{C}$ (37.21 days) on $F$. oxysporum than at $35^{\circ} \mathrm{C}$ (26.11 days) when it fed on $P$. spinosum. The longest period of male individuals was (29.2 days) when mites reared on $P$. spinosum at $20^{\circ} \mathrm{C}$, and shorted to reached (16.6 days ) at $35^{\circ} \mathrm{C}$ when fed on the same fungus. These results showed that the higher temperature decreased the $P$. martini longevity. The statistical analysis of obtained data in Table (1) showed that there were highly significant differences between individuals fed on different diets at different temperatures. L.S. D. at 0.05 level for male individuals was 0.197 and 0.222 for effect of temperatures and diets, respectively but recorded 0.248 and 0.282 for male individuals, respectively.

Preoviposition, oviposition and postoviposition periods: A general glance to the data in Table (2), revealed that $F$. oxysporum was the most favorable food for the mite, $P$. martini where it increased the oviposition period at $20^{\circ} \mathrm{C}$ (27.4 days), but the least favorable diet was recorded for the same fungus at $35{ }^{\circ} \mathrm{C}$ (15.3 days).Female oviposition period elongated as well as temperature increased. However, it clear that preoviposition and oviposition periods were slightly affected with different diets at the 
tested temperatures.The preoviposition period lasted the longest period (4.86 days) when female fed on $F$. oxysporum at $20^{\circ} \mathrm{C}$ and decreased when it fed on the same diet at $35{ }^{\circ} \mathrm{C}$ ( 2.55 days). Also, the postoviposition period had the same trend of preoviposition period where durated 4.86 days on $F$. oxysporum at $20{ }^{\circ} \mathrm{C}$ and 3.31 days at $35^{\circ} \mathrm{C}$ on the same diet, Table (2).

Fecundity: As shown in Table (2), females didn't make any attempts to protect its eggs. Under the conditions used in this experiment, the number of $P$. martini eggs differed depending on whether the mites fed on any of the tested diets, Table (2). As shown by the obtained data the female deposited the highest number of eggs (74.0) at $25^{\circ} \mathrm{C}$. On the other hand, the lowest number of deposited eggs was recorded at 35 ${ }^{\circ} \mathrm{C}$ (50.30 eggs) on free living nematode. Statistical analysis of data showed that L.S.D. at 0.05 level $=0.487$ and 0.548 for effect of temperature and diet, respectively. This result demonstrated that $25^{\circ} \mathrm{C}$. was the most favorable temperature for rearing the cunaxid mite, $P$. martina and these results were coincident with those obtained by El-Khateeb (1998), where she mentioned that low temperature decreased female fecundity of the cunaxid mite, Cunaxa setirostris (Hermann).Also, Khalil et al., (2009) reared the cunaxid mite, Coleoscirus baptos on different fungi and mentioned that 25 ${ }^{\circ} \mathrm{C}$ was the most favorable temperature for rearing this mite where it deposited 95.6 eggs when fed on Aspergillus niger. The same results were observed but on different cunaxid species by Ghallab (2002) where she studied the biological aspects of three cunaxid species, Coleoscirus simplex (Ewing), C. tuberculatus Den Heyer and Pulaeus subterraneus Berlese when reared on the free living nematode, Rhabditella muscicola Chitwood under laboratory conditions at $27 \pm 1{ }^{\circ} \mathrm{C}$ and $75-80 \%$ R.H.The author mentioned that female life cycle was longer than male being 12.8, 13.1 and 15.6 days, while those of male were $12,11.7$ and 13.4 days, respectively. The coleoscirine cunaxid mite $C$. simplex colonizes greenhouse pot cultures of rootknot nematodes (Meloidogyne spp.) in Orlando, Florida, where it preyed on vermiform nematodes and soil arthropods, Walter and Kaplan (1991). This was the first report of nematophagy in a cunaxid mite. The authors added that the cunaxid mite Pulaeus sp. also fed on both arthropods and nematodes, but three species in the Cunaxidinae, Dactyloscirus inermis, Dactyloscirus sp. And Cunaxa sp. Fed only on arthropods. Also, Yassin (2006) investigated the effect of three diets mainly Collembola (Neanurodes sp.), free living nematode, R. muscicola and acarid mite, Tyrophagus putrescentiae (Schrank) on the biological aspects of the cunaxid mite, Cunaxa capreolus Berlese. He reported that Collembola proved to be the suitable prey where as female deposited high number of eggs and longer life span and this might be due to the collembolan contained the highest total sugar and higher relative concentration of glucose contents. 
Table 1. Effect of different diets on the biological aspects of the predacous mite Pulaeus martini at different temperatures.

\begin{tabular}{|c|c|c|c|c|c|c|c|c|c|c|c|c|c|c|c|}
\hline \multicolumn{2}{|c|}{ Biological aspect } & \multicolumn{3}{|c|}{$20^{\circ} \mathrm{C}$} & \multicolumn{3}{|c|}{$25^{\circ} \mathrm{C}$} & \multicolumn{3}{|c|}{$30^{\circ} \mathrm{C}$} & \multicolumn{3}{|c|}{$35^{\circ} \mathrm{C}$} & \multicolumn{2}{|c|}{ L.S.D. at 0.05 level } \\
\hline & & A & B & C & A & B & C & A & B & C & A & B & C & Temp. & Diet \\
\hline \multirow[t]{2}{*}{$\begin{array}{c}\text { Incubation } \\
\text { period }\end{array}$} & $\hat{0}$ & $5.97 \pm 0.05$ & $5.87+0.04$ & $5.81+0.07$ & $4.88+0.05$ & $4.96+0.04$ & $4.91 \pm 0.05$ & $\begin{array}{c}3.87 \pm 0.0 \\
3\end{array}$ & $3.94 \pm 0.03$ & $3.80 \pm 0.02$ & $2.99+0.02$ & $2.87 \pm 0.02$ & $2.84 \pm 0.03$ & 0.059 & 0.078 \\
\hline & q & $5.98 \pm 0.20$ & $5.94 \pm 0.14$ & $5.8 \pm 0.2$ & $4.84 \pm 0.1$ & $4.96 \pm 0.11$ & $4.92 \pm 0.1$ & $\begin{array}{c}3.76 \pm 0.1 \\
2\end{array}$ & $3.88 \pm 0.13$ & $3.76 \pm 0.1$ & $3.13 \pm 0.1$ & $3.34 \pm 0.1$ & $3.27 \pm 0.12$ & 0.018 & 0.020 \\
\hline \multirow[t]{2}{*}{ Life cycle } & $\hat{0}$ & $23.44 \pm 0.7$ & $23.84 \pm 0.2$ & $23.34 \pm 0.1$ & $18.33 \pm 0.2$ & $17.97 \pm 0.7$ & $18.62 \pm 0.5$ & $\begin{array}{c}15.15 \pm 0.1 \\
7\end{array}$ & $15.21 \pm 0.14$ & $15.69+0.16$ & $10.89 \pm 0.24$ & $10.94 \pm 0.16$ & $10.95 \pm 0.05$ & 0.056 & 0.052 \\
\hline & q & $26.94 \pm 0.3$ & $26.96 \pm 0.3$ & $26.6 \pm 0.24$ & $24.61 \pm 0.5$ & $24.5 \pm 0.14$ & $24.06 \pm 0.2$ & $\mid \begin{array}{c}19.17 \pm 0.1 \\
1\end{array}$ & $19.52 \pm 0.14$ & $19.35 \pm 0.12$ & $15.12 \pm 0.2$ & $15.7 \pm 0.13$ & $15.06 \pm 0.06$ & 0.159 & 0.176 \\
\hline \multirow[t]{2}{*}{ Longevity } & $\hat{0}$ & $27.10 \pm 0.84$ & $25.4 \pm 0.97$ & $29.2 \pm 0.67$ & $24.2 \pm 0.11$ & $22.3+0.15$ & $25.4+0.17$ & $\begin{array}{c}20.4 \pm 0.5 \\
5\end{array}$ & $21.7+0.34$ & $19.2 \pm 0.97$ & $17.50 \pm 0.5$ & $15.53 \pm 0.48$ & $16.6+0.52$ & 0.197 & 0.222 \\
\hline & q & $35.53 \pm 1.12$ & $37.21 \pm 0.97$ & $34.22 \pm 1.1$ & $32.8 \pm 0.94$ & $29.36 \pm 0.79$ & $32.1 \pm 0.96$ & $\mid \begin{array}{c}27.65 \pm 0.7 \\
7\end{array}$ & $28.21 \pm 0.83$ & $26.11 \pm 0.75$ & $23.5 \pm 0.9$ & $21.16 \pm 0.82$ & $22.83 \pm 0.95$ & 0.248 & 0.282 \\
\hline \multirow[t]{2}{*}{ Life span } & $\sigma^{2}$ & $50.54 \pm 0.77$ & $49.24 \pm 0.6$ & $52.54 \pm 1.0$ & $42.53+0.6$ & $40.24 \pm 0.75$ & $44.02 \pm 0.7$ & $\begin{array}{c}35.55 \pm 0.3 \\
9\end{array}$ & $36.91 \pm 0.56$ & $34.89 \pm 0.84$ & $28.39 \pm 0.84$ & $26.44 \pm 0.68$ & $27.55 \pm 0.63$ & 0224 & 0251 \\
\hline & q & $62.48 \pm 1.31$ & $61.1 \pm 1.27$ & $60.82 \pm 1.1$ & $57.41 \pm 1.2$ & $53.86 \pm 0.96$ & $56 . \pm 0.87$ & $\begin{array}{c}46.82+0.8 \\
1\end{array}$ & $47.73 \pm 0.84$ & $45.46 \pm 1.12$ & $38.62 \pm 1.17$ & $36.86 \pm 0.91$ & $37.89 \pm 0.96$ & 0.278 & 0.310 \\
\hline
\end{tabular}

$A=$ free living nematode

$\mathrm{B}=$ Fusarium oxysporum

$\mathrm{C}=$ Pythium spinosum 
Table 2. Effect of different diets on the longevity and fecundity of the predacous mite Pulaeus martini female at different temperatures

\begin{tabular}{|c|c|c|c|c|c|c|c|c|c|c|c|c|c|c|}
\hline \multirow[t]{2}{*}{ Biological aspect } & \multicolumn{3}{|c|}{$20^{\circ} \mathrm{C}$} & \multicolumn{3}{|c|}{$25^{\circ} \mathrm{C}$} & \multicolumn{3}{|c|}{$30^{\circ} \mathrm{C}$} & \multicolumn{3}{|c|}{$35^{\circ} \mathrm{C}$} & \multicolumn{2}{|c|}{ L.S.D. at 0.05 level } \\
\hline & A & B & C & A & B & C & A & B & C & A & B & c & Temp. & Diet \\
\hline $\begin{array}{l}\text { Preoviposition } \\
\text { period }\end{array}$ & $4.78 \pm 0.20$ & $4.86 \pm 0.2$ & $4.77 \pm 0.14$ & $4.20 \pm 0.1$ & $4.36 \pm 0.12$ & $4.44 \pm 0.2$ & $3.96 \pm 0.24$ & $3.84 \pm 0.16$ & $3.75 \pm 0.15$ & $2.60 \pm 0.2$ & $2.55 \pm 0.27$ & $2.73 \pm 0.33$ & 0.074 & 0.079 \\
\hline Oviposition period & $25.6 \pm 1.87$ & $27.4 \pm 0.9$ & $24.9 \pm 0.94$ & $22.3 \pm 0.8$ & $20.9 \pm 0.76$ & $23.7 \pm 0.8$ & $19.7 \pm 0.84$ & $20.6 \pm 0.86$ & $18.4 \pm 0.79$ & $17.5 \pm 0.6$ & $15.3 \pm 0.58$ & $16.6 \pm 0.6$ & 0.207 & 0.232 \\
\hline Postoviposition period & $5.14 \pm 0.96$ & $4.86 \pm 0.9$ & $4.55 \pm 0.83$ & $4.30 \pm 0.1$ & $4.10 \pm 0.19$ & $4.0 \pm 0.2$ & $3.99 \pm 0.24$ & $3.77 \pm 0.27$ & $3.96 \pm 0.25$ & $3.4 \pm 0.3$ & $3.31 \pm 0.25$ & $3.5 \pm 0.3$ & 0.164 & 0.179 \\
\hline Fecundity & $55.8 \pm 1.97$ & $56.7 \pm 1.22$ & $56.40 \pm 1.1$ & $73.2 \pm 1.5$ & $73.79 \pm 1.6$ & $74.0 \pm 1.4$ & $66.1 \pm 1.14$ & $67.33 \pm 1.13$ & $66.7 \pm 1.32$ & $50.30 \pm 1.5$ & $52.14 \pm 1.8$ & $48.71 \pm 1.6$ & 0.487 & 0.548 \\
\hline
\end{tabular}




\section{REFERENCES}

1. Arbabi M. and J. Singh 2000. Studies on biological aspects of predacious mite Cunaxa setirostris on Tetranychus ludeni at laboratory condition in Varanasi, India. J Agric Rural Dev 2:13-23

2. Arbabi, M., N. Golmohammadzadeh-Khiaban and M. Askari 2002. Plant mite fauna of Sistan-Baluchestan and Hormozgan provinces. J. Entomol. Soc. Iran. 22 (1): 87105.

3. Charnov,E.L.1976.Optimal foraging: attack strategy of a mantid.Ann.Nat.110:141151.

4. De Castro, T.M.G. and J. Den Heyer 2004. A revision of the genus Pulaeus Den Heyer, with descriptions of a new genus and four new Brazilian species (Acari: Prostigmata: Cunaxidae).Zootaxa, 2141: 20-36

5. De-Oliverira, A. J. and E. Daemon 2003. Quantitative and qualitative assessment of mites (Acari) in the domiciliary dust in the "Zona da Mata" region, Minas Gerais, Brazil. Revvista Brasileira de Zoologia, 20 (4): 675-679.

6. Duncan, D. B. 1955. Multiple range and multiple F-test. Biometrics, 11:1-42.

7. El-Khateeb, H.M.A. 1998. Life tables of some predacious mites and their importance in biological control. Ph.D. Thesis, Fac. Agric. Cairo Univ., 119 pp.

8. Furuichi, H., S. Yano, A. Takafuji and M. Osakabe 2005.Prey preference of the predatory mite, Neoseiulus womersleyi Schicha is determined by spider mite webs. J. Appl. Ent. 129 (6):336-339.

9. Ghallab, M. A. 2002. Ecological, ecological and morphological studies on some predacous mites (Suborder Actinedida). Ph.D. Thesis, Fac. Sci., Cairo Univ., 244 pp.

10. Khalil, A. M., E. M. A. Yassin, M.A.M. Abou Tayesh and S. A. Allam 2009. Effect of different diets on the development and fecundity of the cunaxid mite, Coleoscirus baptos (Chaudhri) (Acari: Cunaxidae). Minufia J. Agric. Res., 34 (3): 1295-1303.

11. Sathiamma B.1995. Biological supression of the white spider mite Oligonychus iseilemae (Hirst) on coconut foliage. Entomon, 20:237-243

12. Schruft, G., 1971. Haleupalus oliveri new species, A "Thorn-palped" mite on grape vines (Vitis spp.) Acari: Cunaxidae. Dutsch. Entomol. Z. 18(4-5): 379-382.

13. Smiley, R. L. 1992. The Predatory Mite Family Cunaxidae (Acari) of the World with a New Classification. Indira Publishing House, Michigan USA 356 pp.

14. Tagore, A. and B. N. Patatunda 2003. Mites associated with some ornamental plants at Hisar, Haryana. Pest Manag. Econ. Zool., 11(1): 37-44.

15. Taha H. A., M.E. El-Naggar, M. M. Abou-El-Nagga and S.M. Soliman 1988. Effect of different prey species on the development and fecundity of the predaceous mite, 
Neocunaxoides andrei Baker \& Hovmann. (Acari: Cunaxidae).Agric Res Rev 66:129135

16. Tatiane M. M., G. de Castro and G. J. de Moraes 2010. Life cycle and behaviour of the predaceous mite Cunaxatricha tarsospinosa (Acari: Prostigmata: Cunaxidae). Exp.Appl. Acarol. (2010) 50:133-139.

17. Walter, D. E. and D. T. Kaplan 1991. Observations on Coleoscirus simplex (Acarina: Prostigmata), a predatory mite that colonizes greenhouse cultures of rootknot nematode (Meloidogyne spp.), and a review of feeding behavior in Cunaxidae. Exp. Appl. Acarol., 12 (1-2): 47-59.

18. Yassin, E. M. A. 2006. Notes on the biological behavior of the predacous mite Cunaxa capreolus Berlese (Acari: Prostigmata: Cunaxidae). Ann. Of Agric. Sci., Moshtohor, 44 (4-5): 1843-1853.

19. Zaher, M. A., Z. R. Soliman and S.M. El-Bishlawy 1975. Feeding habits of the predaceous mite, Cunaxa capreolus (Acarina: Cunaxidae). Entomophaga 20:209212. 


\title{
Pulaeus martini (Den Heyer) (Acari: دورة حياة الاكاروس المفترس عند التغذية على أغذية مختلفة
}

\author{
عابدين محمود خليل ، عصام محمد عبد السلام ياسين ، ممدوح محمد السباعى \\ معهر بحوث وقاية النباتات - مركز البحوث الزراعية - الدقي - جيزة - مصر
}

تهدف هذه الدراسة الى التعرف على المظاهر البيولوجية المختلفة للاكاروس Pulaeus martini المنتمى

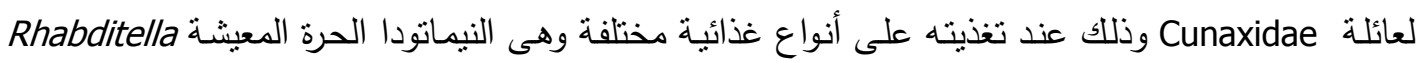
muscicola حرارة 20 و 25 و 30 و 35 مه ورطوبـة نسبية 75 \% . حيث دلت النتائج المتحصـل عليهـا أن المظـاهر البيولوجية لهذا الاكاروس قد تأثرت بصورة معنوية بنوع الغذاء ودرجة الحرارة. ولقد وجد أن الذكور اقل من الإنـاث في مراحل التطور وان درجة الحرارة 20 مه ذادت بشكل معنوي وواضـح فى مدة حياة الأفراد مقارنـة بدرجة الحرارة 35م والتى قللت من طول هذه الفترات. ولقد استغرقت فترة دورة الحياة Life cycle للاكاروس

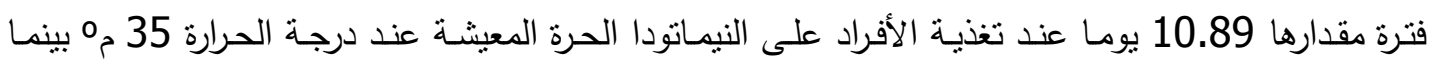
طالت هذه الفترة مسجلة زمنا مقداره 26.96 يوما عند تغذية الإناث على الفطر F. oxysporum عند 20

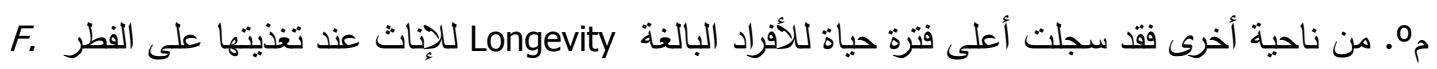
oxysporum 20 مند oxpor (37.21 يوما) بينما قلت هذه الفترة ووصلت لأقل معدل لها مسجلة زمنا مقداره 21.6 يوما عند تغذية الأفراد الذكور على نفس الفطر ولكن عند 35 مo . ومن ناحية أخرى أثرت النيماتودا الحرة المعيشة على طول الفترة الكلية للأفراد Life span للإناث عند 20 مo حيث استغرقت هذه المدة أعلى F. Oxysporum 62.48 يومنا ومقداره اقل فترة سجلت للأفراد الذكور عند تغذيتها على الفطر عند 35 م مسجلة (26.44 يومـا). ومن النتائج المتحصل عليها فى هذه الدراسـة أيضـا أتضـح أن أفضل غذاء لتغذية هذا الاكاروس هو الفطر F. oxysporum عند 25 مo حيث وضعت الأفراد الإناث عددا مقدراه 73.79 بيضـة مقارنـة بـالفطر P. spinosum والذى قلل من عدد البيض الموضوع حيث سجل

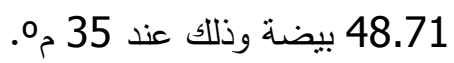

